\title{
POLITIK HUKUM PERBANKAN SYARIAH DI INDONESIA
}

\author{
Muhammad Ramadhan \\ Fakultas Syariah dan Hukum UIN Sumatera Utara \\ Jl. Willem Iskandar Pasar V Medan Estate, Medan, Sumatera Utara, 20371 \\ e-mail: ramadhanm753@gmail.com
}

\begin{abstract}
Abstrak: Politik hukum merupakan sesuatuyang mendasari kebijakan dasar diundangkannya suatu regulasi, dan dasar kebijakan diberlakukannya suatu regulasi tertentu dalam tatanan sistem hukum nasional. Pengaturan dan keberlakuan regulasi perbankan syariah di Indonesia dalam perspektif politik hukum adalah sesuatu yang patut untuk dipahami. Penelitian ini menggunakan metode penelitian kualitatif dengan komparatif deskriptif sebagai analisis berpikirnya. Penelitian ini menunjukkan bahwa regulasi perbankan syariah menjadi cerminan dalam dimensi kebijakan dasar (basic policy). Regulasi perbankan syariah merupakan respons atas perkembangan industri perbankan syariah yang membutuhkan jaminan kepastian hukum dan keadilan hukum dalam suatu regulasi yang jelas. Dalam dimensi kebijakan keberlakuan hukum (enactment policy) regulasi perbankan syariah diyakini memberikan manfaat (utility) dan kemaslahatan bagi masyarakat Indonesia dan dipandang sejalan dengan tujuan ekonomi nasional. Eksistensi regulasi perbankan syariah di Indonesia saat ini memperkuat teori positivisasi hukum Islam dan memperkuat paradigma hukum profetik dalam sistem hukum nasional.
\end{abstract}

\begin{abstract}
Legal Policy of Islamic Banking in Indonesia. Legal policy is something that underlies basic policy of a regulation and a basic policy of enactment specific regulation in the national legal system order. Setting and enforceability of Islamic banking regulations in Indonesia on political law perspective is something that deserves to be understood. This study uses qualitative research with descriptive comparative as its thinking analysis. This study shows that the regulation of Islamic banking was a reflection of basic policy dimension. Islamic banking regulation was a response to growing Islamic banking industry that need of legaly and legal justice in a clear regulation. In the enactment of policy dimension, regulation of Islamic banking is believed to provide utility and benefit for Indonesia people and seen as a goal of national economic objectives. The existence of Islamic banking regulations in Indonesia nowadays reinforces the theory of Islamic law positivism and strengthening the legal prophetic paradigm in the national legal system.
\end{abstract}

Kata Kunci: politik hukum, perbankan syariah, positivisasi, hukum profetik 


\section{Pendahuluan}

Perkembangan mutakhir khususnya pasca reformasi, ekonomi syariah mendapatkan momentumnya untuk dapat disebut berkembang. Menguatnya isu syariah, dapat disebut sebagai bentuk adanya kesadaran baru bagi masyarakat Muslim Indonesia untuk memahami syariah, di mana syariah tidak lagi dimaknai sebagai sesuatu yang normatifabstrak, melainkan sesuatu yang empiris-riil dalam kehidupan. ${ }^{1}$ Penguatan isu syariah ini, secara empiris dikuatkan dengan munculnya berbagai aktivitas ekonomi yang mengatasnamakan syariah, seperti bank syariah, pasar modal syariah, asuransi syariah, dan gadai syariah. Fenomena tersebut adalah realitas yang menjelaskan bahwa isu syariah dijadikan masyarakat Muslim Indonesia sebagai alternatif dalam berbagai aspek kehidupan, termasuk dalam bidang ekonomi. ${ }^{2}$

Pada konteks perbankan tersebut, istilah ekonomi syariah tidak hanya dikenal pada bank Islam atau yang mengatasnamakan Islam saja, tetapi juga ditemukan pengelolaannya dalam perbankan konvensional, di mana dapat dipandang sebagai upaya penguatan ekonomi syariah di bidang perbankan. Munculnya bank-bank konvensional yang belakangan menggunakan nama syariah, seperti BRI Syariah dan BNI Syariah yang membuka model spin off dari induk konvensionalnya atau bank umum konvensional yang membuka Unit Usaha Syariah semisal Bank Sumut. Dapat dipahami bahwa bank syariah mendapatkan perhatian dari para pelaku perbankan konvensional. Terutama dengan kemungkinan, melalui label "syariah" dianggap mampu mencakup ruang nasabah yang lebih luas. ${ }^{3}$ Perkembangan bank syariah tersebut, dianggap membawa kebaikan bagi kepentingan peningkatan ekonomi masyarakat, sehingga ada kesan bahwa kebangkitan ekonomi syariah sebagai kebangkitan ekonomi umat Islam. Walaupun tentu saja dalam praktiknya, bank syariah belum sepenuhnya dapat memenuhi tujuan ideal yang disebut.

Banyak faktor yang menentukan perkembangan perbankan syariah di Indonesia. Menurut Rifki Ismal, beberapa faktor pendukung perkembangan bank syariah di Indonesia. Pertama, jumlah populasi umat Islam yang besar. Kedua, dukungan dari perbankan, pemerintah dan sarjana syariah. Ketiga, kinerja yang baik dari bank syariah dalam dua

${ }^{1}$ Greg Fealy dan Sally White, Expressing Islam: Religious Life and Politicts in Indonesia (Singapore: Institute of Southeast Asian Studies, 2008), h. 3.

${ }^{2}$ Untuk pengalaman Indonesia isu syariah ini tidak hanya ditemukan dalam praktik perbankan, tetapi lebih luas juga diikuti dengan adanya upaya penerapan unsur syariah lainnya, walaupun tentu yang terakhir disebut tidak menjadi fokus tulisan ini. Arskal Salim dan Azyumardi Azra, "Introduction: The State and Shari'a in the Perspective of Indonesian Legal Politics," dalam Arskal Salim dan Azyumardi Azra (ed.,) Shari'a and Politics in Modern Indonesia (Singapore: Institute of Southeast Asian Studies, 2003), h. 1-16.

${ }^{3}$ Muhamad Abduh dan Mohd Azmi Omar, "Islamic Banking and Economic Growth: The Indonesia Experience," dalam International Journal of Islamic and Middle Eastern Finance and Management, Vol. 5, No. 1, 2008), h. 35-47. 
dekade terakhir telah menarik simpati masyarakat. Keempat, perbankan syariah sebagai pilihan dalam kerja ekonomi Indonesia. ${ }^{4}$

Dalam konteks masyarakat Indonesia, tentu saja perkembangan perbankan syariah tidak dapat dipisahkan dari dukungan umat Islam sebagai masyarakat mayoritas. Harapannya, perkembangan perbankan syariah di Indonesa mampu mengimbangi perkembangan perbankan syariah di negara lainnya, seperti di kawasan Asia Tenggara. Dukungan lainnya yang tentu saja tidak bisa diabaikan, adalah dukungan pemerintah yang secara khusus memperkuat eksistensi perbankan syariah di Indonesia. ${ }^{5}$

Perkembangan perbankan syariah ini tentu saja muncul sebagai sesuatu harapan baru bagi kepentingan umat Islam Indonesia, walaupun tentu saja harapan ini masih jauh dari yang diinginkan. Realitas masih menunjukkan bahwa market share perbankan syariah hingga saat ini masih di bawah 5\%. Akan tetapi, kehadiran perbankan syariah ini masih dapat disebut mampu menarik perhatian umat Islam untuk menjadi bagian di dalamnya, terutama upaya umat Islam untuk terbebas dari perilaku riba yang bertentangan dengan ajaran Islam.

Menyadari perkembangan perbankan syariah ini, negara memandang perlu memberikan pengaturan (regulasi) yang jelas terhadap eksistensi perbankan syariah. Regulasi perbankan syariah telah mengalami sejumlah tahapan dan proses yang telah dilalui dalam konstelasi politik hukum nasional. Tulisan ini akan melihat bagaimana sesungguhnya politik hukum perbankan syariah di Indonesia. Pada prinsipnya politik hukum memiliki dua dimensi. Pertama, kebijakan dasar (basic policy) yaitu politik hukum yang menjadi alasan dasar diadakannya suatu peraturan perundang-undangan. Kedua, tujuan atau alasan yang muncul di balik pemberlakuan suatu peraturan perundang-undangan (enactment policy). Dimensi kedua ini menjadi hal yang menarik karena peraturan perundang-undangan seringkali dijadikan oleh penguasa sebagai instrumen politik bagi pemerintah.

Politik hukum perbankan syariah di Indonesia menjadi menarik untuk dikaji karena melibatkan sumber hukum yang berasal dari ajaran agama Islam yang dalam bahasa yang lebih populer disebut positifisasi hukum Islam. Terbitnya sejumlah regulasi antara lain Undang-Undang Nomor 3 tahun 2006 tentang Peradilan Agama yang memberikan kewenangan absolut Peradilan Agama untuk menangani sengketa ekonomi syariah dan UU Nomor 21 tahun 2008 tentang Perbankan Syariah yang memberikan pilihan forum (choice offorum) penyelesaian sengketa di antara Peradilan Agama dan Peradilan Umum patut untuk didalami. Kajian politik hukum perbankan syariah di Indonesia ini semakin menjadi menarik lagi setelah keluarnya Putusan Mahkamah Konstitusi Nomor 93/PUU-X/2012.

${ }^{4}$ Rifki Ismal, Islamic Banking in Indononesia: New Perspectives on Monetary and Financial Issue (England: John Wiley \& Sons, Ltd, Chichester, 2013), h. 73-74.

${ }^{5}$ Rodney Wilson, Legal, Regulatory and Governance Issues in Islamic Finance (Edinburgh: Edinburgh University Press, 2012), h. 131. 


\section{Dinamika dan Konstelasi Regulasi Perbankan Syariah di Indonesia}

Secara yuridis formal, regulasi perbankan syariah pada awalnya diatur dalam UU Nomor 7 Tahun 1992 tentang perbankan. ${ }^{6}$ Pada UU ini akomodasi terhadap perbankan syariah dilakukan dengan mengakui keberadaan bank yang beroperasi dengan prinsip bagi hasil baik bank umum maupun BPRS. Hanya saja pada UU ini tidak disebut apa definisi dari bank yang beroperasi dengan prinsip bagi hasil. Definisi bank yang beroperasi dengan prinsip bagi hasil disebutkan dalam PP Nomor 72 tahun 1992 tentang bank berdasarkan prinsip bagi hasil, Pasal 2 yang menyebutkan prinsip bagi hasil yang digunakan oleh bank berdasarkan prinsip bagi hasil dalam menetapkan imbalan yang akan diberikan kepada masyarakat sehubungan dengan penggunaan/pemanfaatan dana masyarakat yang dipercayakan kepadanya, menetapkan imbalan yang akan diterima sehubungan dengan penyediaan dana masyarakat dalam bentuk pembiayaan baik untuk keperluan investasi maupun modal kerja termasuk kegiatan usaha jual beli dan menetapkan imbalan yang akan diterima sehubungan dengan kegiatan usaha lainnya yang lazim dilakukan oleh bank dengan prinsip bagi hasil.

Selanjutnya pada tahun 1998, istilah bank dengan prinsip bagi hasil diperbaiki dengan terbitnya UU Nomor 10 tahun $1998^{7}$ tentang perubahan UU Nomor 7 tahun 1992 yang mengakui keberadaan bank syariah dan bank konvensional serta memperkenankan bank konvensional membuka kantor cabang syariah. Istilah yang disebutkan untuk mengganti bank dengan prinsip bagi hasil adalah bank berdasarkan prinsip syariah. Pada UU Nomor 10 tahun 1998 pada pasal 1 angka 3 disebutkan bahwa definisi prinsip syariah adalah aturan perjanjian berdasarkan hukum Islam antara bank dan pihak lain untuk penyimpanan dana, dan atau pembiayaan kegiatan usaha, atau kegiatan lainnya yang dinyatakan sesuai dengan syariah, antara lain pembiayaan berdasarkan prinsip bagi hasil (mudhârabah), pembiayaan berdasarkan penyertaan modal (musyârakah), prinsip jual beli barang dengan memperoleh keuntungan (murâbahah), atau pembiayaan barang modal berdasarkan prinsip sewa murni tanpa pilihan (ijârah), atau dengan adanya pilihan pemindahan kepemilikan atas barang yang disewa dari pihak bank oleh pihak lain (ijârah wa iqtina').

Selanjutnya pada tahun 1999 terbit UU Nomor 23 Tahun 1999 tentang Bank Indonesia, ${ }^{8}$ sebagaimana telah dirubah dengan UU Nomor 3 Tahun 2004 tentang perubahan atas UU Republik Indonesia Nomor 23 Tahun 1999 tentang Bank Indonesia, ${ }^{9}$ kemudian dirubah

${ }^{6}$ Diundangkan pada 25 Maret 1992 dalam Lembaran Negara Republik Indonesia Tahun 1992 Nomor 32 dan Tambahan Lembaran Negara Republik Indonesia Nomor 3473.

${ }^{7}$ Diundangkan pada 10 Nopember 1998 dalam Lembaran Negara Republik Indonesia Tahun 1998 Nomor 182 dan Tambahan Lembaran Negara Republik Indonesia Nomor 3790.

${ }^{8}$ Diundangkan pada 17 Mei 1999 dalam Lembaran Negara Republik Indonesia Tahun 1999 Nomor 66 dan Tambahan Lembaran Negara Republik Indonesia Nomor 3843.

${ }^{9}$ Diundangkan pada 15 Januari 2004 dalam Lembaran Negara Republik Indonesia Tahun 2004 Nomor 7 dan Tambahan Lembaran Negara Republik Indonesia Nomor 4357. 
dengan Peraturan Pemerintah Pengganti Undang-undang Nomor 2 Tahun 2008 tentang perubahan kedua atas UU Nomor 23 Tahun 1999 tentang Bank Indonesia, ${ }^{10}$ sebagaimana telah ditetapkan dalam UU Nomor 6 Tahun 2009 tentang penetapan Peraturan Pemerintah Pengganti Undang-undang Nomor 2 Tahun 2008 tentang perubahan kedua atas UU Nomor 23 Tahun 1999 tentang Bank Indonesia Menjadi UU, ${ }^{11}$ selanjutnya disebut dengan UU Bank Indonesia. Dalam UU tentang Bank Indonesia ini diakomodasi kebijakan moneter berdasarkan prinsip syariah di mana Bank Indonesia bertanggung jawab terhadap pengaturan dan pengawasan bank komersial termasuk bank syariah. BI dapat menetapkan kebijakan moneter dengan menggunakan prinsip syariah.

Pada tahun 2000, Majelis Ulama Indonesia membentuk Dewan Syariah Nasional (DSN) yang memiliki tugas pokok salah satunya mengkaji, menggali, dan merumuskan nilai dan prinsip-prinsip syariah dalam bentuk fatwa untuk dijadikan pedoman dalam kegiatan transaksi pada lembaga keuangan syariah. DSN MUI bertugas dan memiliki kewenangan untuk menetapkan fatwa tentang produk dan jasa dalam kegiatan usaha bank yang melaksanakan kegiatan usaha berdasarkan prinsip syariah.

Fatwa-fatwa DSN MUI umumnya dipergunakan menjadi landasan bagi ketentuan atau peraturan yang dikeluarkan oleh instansi yang berwenang seperti Kementerian Keuangan dan Bank Indonesia di bidang perbankan syariah, pasar modal syariah, asuransi syariah, dan lembaga keuangan syariah lainnya. Pada bidang perbankan syariah, Bank Indonesia menjadikan fatwa-fatwa DSN MUI di bidang perbankan syariah sebagai landasan dalam pembuatan Peraturan Bank Indonesia (PBI) serta Surat Edaran Bank Indonesia (SEBI) yang mengatur kegiatan usaha bank berdasarkan prinsip syariah pada Bank Umum Syariah (BUS), Unit Usaha Syariah yang dibuka oleh Bank Umum Konvensional, dan Bank Pembiayaan Rakyat Syariah (BPRS).

Dalam kaitan fatwa DSN MUI dengan kegiatan usaha bank syariah, sejumlah PBI telah diterbitkan. Ketentuan mengenai bank umum yang melaksanakan kegiatan usaha berdasarkan prinsip syariah diatur dalam PBI Nomor 6/24/PBI/2004 yang mewajibkan adanya Dewan Pengawas Syariah (DPS) dalam setiap bank syariah yang bertugas mengawasi penerapan syariah dalam kegiatan usaha bank. Ketentuan mengenai Bank Pembiayaan Rakyat yang melaksanakan kegiatan usaha berdasarkan prinsip syariah diatur dalam PBI Nomor 6/17/2004.

Selanjutnya terdapat sejumlah Peraturan Bank Indonesia yang berpedoman pada fatwa-fatwa DSN MUI yaitu antara lain PBI Nomor 7/46/PBI/2005 tentang Akad Penghimpunan dan Penyaluran Dana Bagi Bank Yang Melaksanakan Kegiatan Usaha Berdasarkan

${ }^{10}$ Diundangkan pada 13 Oktober 2008 dalam Lembaran Negara Republik Indonesia Tahun 2008 Nomor 142 dan T] ambahan Lembaran Negara Republik Indonesia Nomor 4901.

${ }^{11}$ Diundangkan pada 13 Januari 2009 dalam Lembaran Negara Republik Indonesia Tahun 2009 Nomor 7 dan Tambahan Lembaran Negara Republik Indonesia Nomor 4962. 
Prinsip Syariah. Dalam penjelasan umum PBI Nomor 7/46/PBI/2005 ini dijelaskan bahwa ketentuan persyaratan minimum akad yang diatur ketentuan itu disusun dengan berpedoman kepada fatwa yang diterbitkan oleh DSN. PBI Nomor 7/47/PBI/2005 dan PBI Nomor 8/3/PBI/2005.

UU Nomor 21 Tahun 2008 tentang Perbankan Syariah ${ }^{12}$ selanjutnya disebut dengan UU Perbankan Syariah disahkan. Istilah yang digunakan dari sebelumnya bank berdasarkan prinsip syariah diubah dengan istilah bank syariah. Terdapat dua bentuk bank yang menjalankan prinsip syariah dalam UU ini yaitu BUS dan BPRS. Definisi prinsip syariah dalam UU Nomor 21 tahun 2008 berbeda dengan pengertian yang disebutkan dalam UU Nomor 10 tahun 1998. Dalam UU Nomor 21 tahun 2008 disebutkan prinsip syariah adalah hukum Islam dalam kegiatan perbankan berdasarkan fatwa yang dikeluarkan oleh lembaga yang memiliki kewenangan dalam penetapan fatwa di bidang syariah.

Berdasarkan sejumlah regulasi yang mengatur perbankan syariah tersebut, terlihat jelas bahwa pengaturan perbankan syariah pada awalnya masih diatur dalam ruang lingkup perbankan secara umum, sebab pada tahap awal perbankan syariah masih dianggap tidak terpisahkan dari perbankan konvensional. Pada gilirannya, pengaturan perbankan syariah diatur dalam UU yang khusus tentang perbankan syariah. Pengaturan UU Perbankan Syariah ini, tentu saja berkaitan dengan keyakinan bahwa perbankan syariah tidak lagi dapat disamakan dengan perbankan konvensional, sehingga diperlukan adanya pengaturan khusus yang menunjukkan bahwa perbankan syariah merupakan sebuah sistem yang terpisah, yaitu sistem perbankan syariah.

\section{Politik Hukum Perbankan Syariah di Indonesia}

Pengaturan regulasi Perbankan Syariah dapat dilihat dari perspektif politik hukum. Eksistensi hukum dalam suatu negara menjadi suatu persyaratan utama untuk dapat menjalankan kehidupan negara dan masyarakat dan menciptakan ketertiban dan kedamaian. Hukum yang diberlakukan haruslah memiliki nilai-nilai yang dapat diterapkan oleh masyarakat setempat. Sistem hukum nasional di Indonesia sangat terkait dengan dasar hukum negara Pancasila sebagai pusat dalam pembentukan sistem hukum nasional yang diikuti oleh konstitusi UUD 1945 sebagai landasan setiap hukum yang diberlakukan baik peraturan perundang-undangan, yurisprudensi, dan hukum kebiasaan.

Politik hukum (legal policy) merupakan tujuan dan alasan di balik dibentuknya peraturan perundangan. Politik hukum merupakan sesuatu hal yang penting dalam memahami mengapa diperlukan pembentukan suatu peraturan perundang-undangan dan menentukan apa yang hendak diterjemahkan ke dalam kalimat hukum dan menjadi perumusan dalam

${ }^{12}$ Diundangkan pada 16 Juli 2008 dalam Lembaran Negara Republik Indonesia Tahun 2008 Nomor 94 dan Tambahan Lembaran Negara Republik Indonesia Nomor 4867. 
pasal-pasal. Politik hukum nasional meliputi dua hal. Pertama, pembangunan hukum yang berisikan pembuatan dan pembaruan terhadap materi-materi hukum agar dapat sesuai dengan kebutuhan. Kedua, pelaksanaan ketentuan hukum yang telah ada termasuk penegasan fungsi-fungsi lembaga dan pembinaan para penegak hukum. ${ }^{13}$

Politik hukum nasional mencakup proses pembuatan hukum dan pelaksanaan hukum yang dapat menunjukkan sifat dan ke arah mana hukum akan dibangun dan ditegakkan. Politik hukum merupakan arah resmi yang dijadikan pijakan dan cara untuk membuat dan melaksanakan hukum dalam rangka mencapai tujuan bangsa dan negara. Politik hukum menjadikan suatu hukum menjadi bagian dari proses pencapaian tujuan negara lewat jalur formil kenegaraan.

Pengaturan perbankan syariah merupakan kesadaran dan kebijakan pemerintah dalam menetapkan regulasi yang akan diberlakukan, yaitu menetapkan pengaturan di mana kedudukan perbankan syariah sama seperti perbankan konvensional lainnya, terutama dalam pengaturannya perbankan syariah dibedakan dengan perbankan konvensional. ${ }^{14}$ Perbankan syariah dan konvensional diregulasi dalam batasan yang jelas. Bank umum dapat membuka BUS yang beroperasi secara penuh berdasarkan prinsip syariah. Bagi Bank Umum Konvensional dapat membuka Unit Usaha Syariah yang dipersyaratkan untuk memisahkan diri (spin off) dari induk konvensional dalam kurun waktu tertentu.

Pengaturan UU Perbankan Syariah merupakan respons pemerintah terhadap keberadaan perbankan syariah itu sendiri, di mana perbankan syariah tidak lagi hanya dipandang sebagai sistem perbankan baru, tetapi lebih dari itu juga memiliki peluang untuk dapat bersaing dengan perbankan konvensional, atau bahkan mungkin juga mampu melampaui perbankan konvensional. Namun muncul pertanyaan, apa sejatinya argumentasi yang menjustifikasi intervensi pemerintah terhadap pengaturan perbankan syariah di Indonesia? Pertanyaan filosofis tersebut, menjadi salah satu gagasan dalam penelitian ini untuk menggali politik hukum perbankan syariah di Indonesia terutama untuk melihat keterlibatan pemerintah dalam meregulasi perbankan syariah. Apakah pemerintah sudah memberikan kewenangan secara penuh kepada pelaku industri syariah dan institusi yang melengkapinya. Ataukah pemerintah masih sebatas retorika dalam meregulasi perbankan syariah di Indonesia.

Menyadari akan hal tersebut, guna melengkapi pengaturan terhadap UU Perbankan Syariah tentu dilihat pula pola penyelesaian sengketa perbankan syariah yang berlaku di Indonesia. Kewenangan penyelesaian sengketa perbankan syariah sudah diatur dalam UU Nomor 3 Tahun 2006 tentang perubahan atas UU Nomor 7 Tahun 1989 tentang Peradilan

${ }^{13}$ Hikmahanto Juwana, "Politik Hukum Undang-undang Ekonomi di Indonesia," dalam Jurnal Hukum, Vol. 01 Tahun 2005, h. 24.

${ }^{14}$ Mohamed Ariff, "Islamic Banking: A Southeast Asian Perspective", dalam Mohamed Ariff (ed.), Islamic Banking in Southeast Asia (Singapore: Institute of Southeast Asian Studies, 1988), h. 210. 
Agama, ${ }^{15}$ selanjutnya disebut dengan UU Peradilan Agama. Sebagaimana Pasal 49 UU Peradilan Agama secara tegas menyebutkan, bahwa "Pengadilan Agama bertugas dan berwenang memeriksa, memutus, dan menyelesaikan perkara di tingkat pertama antara orang-orang yang beragama Islam di bidang ekonomi syariah."16

Ekonomi syariah yang dimaksud adalah perbuatan atau kegiatan usaha yang dilaksanakan menurut prinsip syariah, antara lain meliputi bank syariah, lembaga keuangan mikro syariah, asuransi syariah, reasuransi syariah, reksa dana syariah, obligasi syariah dan surat berharga berjangka menengah syariah, sekuritas syariah, pembiayaan syariah, pegadaian syariah, dana pensiun lembaga keuangan syariah, dan bisnis syariah. ${ }^{17}$ Namun, kajian ini tetap memfokuskan penelitian pada aspek perbankan syariah.

Pasal 50 ayat (1) UU Peradilan Agama mengatur, bahwa "Dalam hal terjadi sengketa hak milik atau sengketa lain dalam perkara sebagaimana dimaksud dalam Pasal 49, khusus mengenai objek sengketa tersebut harus diputus lebih dahulu oleh pengadilan dalam lingkungan Peradilan Umum." 18 Selanjutnya dalam ayat (2) menetapkan, bahwa "Apabila terjadi sengketa hak milik sebagaimana dimaksud pada ayat (1) yang subjek hukumnya antara orang-orang yang beragama Islam, objek sengketa tersebut diputus oleh Pengadilan Agama bersama-sama perkara sebagaimana dimaksud dalam pasal 49."19

Berdasarkan ketentuan tersebut, dapat dipahami bahwa Pengadilan Agama dapat memutuskan sengketa hak milik, termasuk di bidang ekonomi syariah, secara khusus

${ }^{15}$ Diundangkan pada 20 Maret 2006 dalam Lembaran Negara Republik Indonesia Tahun 2006 Nomor 22 dan Tambahan Lembaran Negara Republik Indonesia Nomor 4611.

${ }^{16}$ Pasal 49 UU Nomor 3 Tahun 2006 tentang Perubahan atas UU Nomor 7 Tahun 1989 tentang Peradilan Agama. Lihat juga Arskal Salim, Contemporary Islamic Law in Indonesia: Sharia and Legal Pluralism (Edinburgh: Edinburgh University Press Ltd, 2005), h. 43.

${ }^{17}$ Penjelasan Pasal 49 huruf i UU Nomor 3 Tahun 2006 tentang Perubahan atas UU Nomor 7 Tahun 1989 tentang Peradilan Agama.

${ }^{18}$ Pasal 50 ayat (1) UU Nomor 3 Tahun 2006 tentang Perubahan atas UU Nomor 7 Tahun 1989 tentang Peradilan Agama.

${ }^{19}$ Pasal 50 ayat (2) UU Nomor 3 Tahun 2006 tentang Perubahan atas UU Nomor 7 Tahun 1989 tentang Peradilan Agama. Penjelasan Pasal 50 ayat (2) menyebutkan, bahwa "Ketentuan ini memberi wewenang kepada pengadilan agama untuk sekaligus memutuskan sengketa milik atau keperdataan lain yang terkait dengan objek sengketa yang diatur dalam Pasal 49 apabila subjek sengketa antara orang-orang yang beragama Islam. Hal ini menghindari upaya memperlambat atau mengulur waktu penyelesaian sengketa karena alasan adanya sengketa milik atau keperdataan lainnya tersebut sering dibuat oleh pihak yang merasa dirugikan dengan adanya gugatan di Pengadilan Agama. Sebaliknya, apabila subjek yang mengajukan sengketa hak milik atau keperdataan lain tersebut bukan yang menjadi subjek bersengketa di pengadilan agama, sengketa di pengadilan agama ditunda untuk menunggu putusan gugatan yang diajukan ke pengadilan di lingkungan Peradilan Umum. Penangguhan dimaksud hanya dilakukan jika pihak yang berkeberatan telah mengajukan bukti ke Pengadilan Agama bahwa telah didaftarkan gugatan di Pengadilan Negeri terhadap objek sengketa yang sama dengan sengketa di Pengadilan Agama. Dalam hal objek sengketa lebih dari satu objek dan yang tidak terkait dengan objek sengketa yang diajukan keberatannya, Pengadilan Agama tidak perlu menangguhkan putusannya, terhadap objek sengketa yang tidak terkait dimaksud. 
adalah perbankan syariah, sepanjang subjek hukumnya antara orang-orang yang beragama Islam. Ketentuan tersebut sekaligus membatasi sengketa hak milik bagi subjek hukum Muslim dan non Muslim, harus diselesaikan lebih dahulu di Peradilan Umum. Ketentuan tersebut melahirkan sejumlah pertanyaan, yaitu bukankah nasabah perbankan syariah tidak hanya dibatasi terhadap subjek hukum Muslim saja? Bukankah subjek hukum Non Muslim dapat menjadi nasabah perbankan syariah? Bagaimana jika terjadi sengketa hak milik di sana? Haruskah juga diselesaikan di lingkungan Peradilan Umum? Bukankah kewenangan Pengadilan Agama dalam menyelesaikan sengketa di bidang ekonomi syariah adalah kompetensi absolut, yang melihat sistem ekonominya dan bukan melihat agama subjek hukumnya? Maka wajar jika Hikmahanto Juwana menyebutkan, bahwa secara praktis kewenangan Pengadilan Agama ini tidak dapat direalisasikan sepenuhnya berdasarkan UU Peradilan Agama, karena Pengadilan Agama tidak memiliki wewenang sebagai lembaga eksekutor dalam memutuskan sengketa ekonomi syariah. ${ }^{20}$

Dalam perspektif politik hukum, ketentuan Pasal 50 UU Peradilan Agama tersebut menegaskan adanya tarik menarik kepentingan antara Pengadilan Agama dengan Pengadilan Umum dalam hal penyelesaian sengketa ekonomi syariah, dalam hal ini perbankan syariah. Sebab, penyelesaian sengketa hak milik antara subjek hukum non Muslim harus diselesaikan di Pengadilan Umum terlebih dahulu, walaupun objek sengketa berada di ranah ekonomi syariah. Sebagaimana diketahui, bahwa subjek hukum non Muslim dapat menjadi nasabah di perbankan syariah, atau secara luas bahwa subjek hukum non Muslim dapat menggunakan ekonomi syariah. Dengan demikian, sejatinya penyelesaian sengkata ekonomi syariah tidak terbatas hanya terhadap subjek hukum Muslim saja, tetapi juga terhadap subjek hukum Non Muslim juga, sepanjang objek sengketanya berada pada ranah ekonomi syariah, dalam hal ini perbankan syariah.

Tarik menarik kewenangan ini, menjelaskan adanya persoalan politik hukum pemerintah dalam meregulasi perbankan syariah khususnya terkait kewenangan penyelesaian sengketa ekonomi syariah. Secara khusus, politik hukum penyelesaian sengketa ekonomi syariah ini, terkait dengan pembatasan ruang dan kewenangan Pengadilan Agama dalam penyelesaian sengketa hak milik, yakni dengan subjek hukum non Muslim. Lalu pertanyaannya, bagaimana jika pemilik perbankan syariah tersebut adalah non Muslim? Bukankah pemilik perbankan syariah juga disebut sebagai subjek hukum? Bagaimana jika terjadi sengketa kepemilikan dengan nasabahnya yang subjek hukumnya Muslim? Apakah juga sengekta kepemilikannya diselesaikan di Pengadilan Umum? Walaupun sengketa kepemilikan tersebut berada di area perbankan syariah (ekonomi syariah)? Pengalihan wewenang penyelesaian sengketa hak milik antar subjek hukum non Muslim tersebut, walaupun di bidang ekonomi syariah,

${ }^{20} \mathrm{Hikmahanto}$ Juwana, et al. "Sharia Law as A System of Governance in Indonesia: The Development of Islamic Financial Law," dalam Wiscoinsin International Law Journal, Vol. 25, No. 4, 2008, h. 783. 
jelas tidak memberi ruang yang utuh dan sepenuhnya kepada Pengadilan Agama dalam penyelesaian sengketa ekonomi syariah.

Dalam perspektif politik hukum, kewenangan penyelesaian sengketa perbankan syariah (ekonomi syariah), tentu tidak dapat dipisahkan dari unsur filosofis, politis dan sosiologis. Walaupun pengaturan UU Perbankan Syariah telah ditetapkan, namun tidak dapat dipisahkan dari prinsipnya untuk menjaga dan mengatur kepentingan umat Islam. Bahkan Abdul Manan berpandangan, dalam perspektif politik hukum penentuan wewenang Pengadilan Agama dalam sengketa ekonomi syariah, masih berkaitan dengan kuatnya teori receptie Snouck Hurgronje, di mana hukum Islam masih dianggap lebih rendah dibandingkan hukum lainnya. Sedangkan Pengadilan Agama masih dianggap sebagai peradilan semu, karena pengaruh citra inferior yang masih sulit dihilangkan, serta ditambah lagi belum kuatnya regulasi tentang ekonomi syariah, menambah kecurigaan masyarakat pada operasional lembaga keuangan syariah. ${ }^{21}$

Hingga pada titik ini, perlu dipertanyakan, bagaimana sesungguhnya pengaturan perbankan syariah di Indonesia? Serta bagaimana penegakan hukumnya jika terjadi sengketa antar para pihak? Secara khusus mempertanyakan, bagaimana pengaturan perbankan syariah sebagaimana dalam UU Perbankan Syariah? Serta bagaimana penegakan hukumnya jika terjadi sengketa dalam UU Pengadilan Agama? Hingga akhirnya mempertanyakan bagaimana seharusnya pengaturan penyelesaian sengketa perbankan syariah di Indonesia?

Secara empiris, pengalaman Pengadilan Agama dalam penyelesaian sengketa perbankan syariah sangat minim. Problematika terletak pada keahlian Pengadilan Agama dalam menyelesaikan sengekta perbankan syariah tersebut. Sebagai regulasi yang dapat dikatakan baru, Pengadilan Agama masih mengalami keterbatasan hakim yang ahli di bidang perbankan syariah, agar lembaga tersebut dapat disebut kreadibel dalam penyelesaian sengketa perbankan syariah. Ketersediaan sumberdaya manusia (SDM) di bidang perbankan syariah di Pengadilan Agama, masih belum tersedia secara khusus, padahal itu menjadi syarat utama untuk mampu menangani kasus-kasus yang terjadi. Selain itu, sebagai kasus baru tentu saja sengketa perbankan syariah belum memiliki yurisprudensi yang cukup banyak, sehingga dapat membantu dan mempermudah penyelesaian sengketa yang terjadi.

Persoalan politik hukum perbankan syariah terus berlanjut, walaupun setelah terbitnya UU Nomor 50 Tahun 2009 tentang perubahan kedua atas UU Nomor 7 Tahun 1989 tentang Peradilan Agama, ${ }^{22}$ selanjutnya disebut juga dengan UU Peradilan Agama. Ketentuan Pasal 3 A ayat (1) UU Peradilan Agama menyebutkan, bahwa "di lingkungan Peradilan Agama

${ }^{21}$ Abdul Mannan, "Hukum Perbankan Syariah," dalam Jurnal Mimbar Hukum dan Peradilan, Vol. 1, No. 7, 2012, h. 5.

${ }^{22}$ Diundangkan pada 29 Oktober 2009 dalam Lembaran Negara Republik Indonesia Tahun 2009 Nomor 159 dan Tambahan Lembaran Negara Republik Indonesia Nomor 5078. 
dapat dibentuk pengadilan khusus yang diatur dengan UU." ${ }^{23}$ Selanjutnya ketentuan Pasal 3A ayat (3) UU Peradilan Agama mengatur, bahwa "pada pengadilan khusus dapat diangkat hakim ad hoc untuk memeriksa, mengadili, dan memutus perkara, yang membutuhkan keahlian dan pengalaman dalam bidang tertentu dan dalam jangka waktu tertentu." ${ }^{24}$ Sebagaimana penjelasan Pasal 3A ayat (3) menyebutkan, bahwa "Tujuan diangkatnya "hakim ad hoc" adalah untuk membantu penyelesaian perkara yang membutuhkan keahlian khusus misalnya kejahatan perbankan syariah dan yang dimaksud dalam "jangka waktu tertentu" adalah bersifat sementara sesuai dengan ketentuan peraturan perundang-undangan." 25

Ketentuan Pasal 3A UU Peradilan Agama tersebut menjustifikasi pandangan sebelumnya, bahwa Pengadilan Agama belum memiliki ketersediaan SDM yang cukup untuk menyelesaikan sengketa perbankan syariah, sehingga membutuhkan dibentuknya pengadilan khusus. Selanjutnya, bahwa pengadilan khusus tersebut hanya berlaku untuk memeriksa, mengadili, dan memutus perkara yang subjek hukumnya terbatas pada orang-orang yang beragama Islam saja. ${ }^{26}$ Ketentuan demikian, ternyata membatasi kewenangan Pengadilan Agama pada subjek hukum non Muslim yang melakukan kejahatan perbankan syariah. Karena peristiwa hukum yang demikian menjadi kompetensi absolut Pengadilan Umum.

Kondisi ini mempertanyakan kewenangan Pengadilan Agama dalam penyelesaian sengketa perbankan syariah. Pandangan tersebut dapat dibenarkan, jika dilihat dari sedikitnya jumlah kasus sengketa ekonomi syariah yang ada di Pengadilan Agama. Walaupun butuh penelitian lebih lanjut tentang kenyataan rendahnya kepercayaan pengelola lembaga keuangan syariah, untuk menyelesaikan masalahnya di Pengadilan Agama.

Ketidakjelasan kewenangan Pengadilan Agama dalam penyelesaian sengketa perbankan syariah makin dipertegas dengan terbitnya Pasal 55 ayat (2) dan (3) UU Nomor 21 Tahun 2008 tentang Perbankan Syariah. Dalam Pasal 55 ayat (1) disebutkan "Penyelesaian sengketa perbankan syariah dilakukan oleh pengadilan dalam lingkungan Peradilan Agama". Namun, dalam Pasal 55 ayat (2) disebutkan bahwa "Dalam hal para pihak telah memperjanjikan penyelesaian sengketa selain sebagaimana dimaksud pada ayat (1), penyelesaian sengketa dilakukan sesuai dengan isi akad". Selanjutnya dalam Pasal 55 ayat (3) berbunyi "Penyelesaian sengketa sebagaimana dimaksud pada ayat (2) tidak boleh bertentangan dengan prinsip syariah."

${ }^{23}$ Pasal 3A ayat (1) UU Nomor 50 Tahun 2009 tentang Perubahan Kedua atas UU Nomor 7 Tahun 1989 tentang Peradilan Agama.

${ }^{24}$ Pasal 3A ayat (3) UU Nomor 50 Tahun 2009 tentang Perubahan Kedua atas UU Nomor 7 Tahun 1989 tentang Peradilan Agama.

${ }^{25}$ Penjelasan Pasal 3A ayat (3) UU Nomor 50 Tahun 2009 tentang Perubahan Kedua atas UU Nomor 7 Tahun 1989 tentang Peradilan Agama.

${ }^{26}$ Peradilan Agama adalah peradilan bagi orang-orang yang beragama Islam. Lihat Pasal 1 angka 1 UU Nomor 50 Tahun 2009 tentang Perubahan Kedua atas UU Nomor 7 Tahun 1989 tentang Peradilan Agama. 
Menurut catatan Mahkamah Agung, sepanjang tahun 2012 hanya ditemukan 31 kasus sengketa ekonomi syariah yang diterima. Jika dibandingkan dengan jumlah Pengadilan Agama dan/atau Mahkamah Syariah di seluruh Indonesia, yakni sebanyak 359 Pengadilan Agama dan/atau Mahkamah Syariah, maka masing-masing Pengadilan Agama dan/atau Mahkamah Syariah hanya menangani perkara ekonomi syariah sebanyak 0,01\% dari total perkara sengketa ekonomi syariah. ${ }^{27}$

\section{Politik Hukum Perbankan Syariah di Indonesia Pasca Putusan MK Nomor 93/PUU-X/2012}

Mahkamah Konstitusi (MK) melalui Putusan MKNomor 93/PUU-X/2012 telah menyatakan semua penjelasan Pasal 55 ayat (2) UU Nomor 21 Tahun 2008 tentang perbankan syariah bertentangan dengan konstitusi dan tidak memiliki kekuatan hukum mengikat. Namun, Pasal 55 ayat (2) yang merupakan pasal induk dan tetap berlaku serta memiliki kekuatan hukum mengikat. Putusan ini berdasarkan pertimbangan Majelis Hakim bahwa penjelasan Pasal 55 ayat (2) yang membuka choice of forum dalam penyelesaian sengketa perbankan syariah akan mengakibatkan tumpang tindih kewenangan dan menyebabkan kekacauan hukum.

Konsekuensi konstitusional dari putusan ini adalah sejak adanya putusan tersebut, maka lembaga di lingkungan Peradilan Agama menjadi satu-satunya lembaga peradilan yang berwenang mengadili perkara sengketa perbankan syariah. Dengan demikian tidak ada lagi dualisme kewenangan lembaga peradilan antara Peradilan Agama dan Peradilan Negeri dalam memutus perkara ekonomi syariah yang dipandang dapat menyebabkan kebingungan dan tumpang tindih kewenangan antara dua lembaga peradilan di atas.

Berdasarkan kondisi di atas dalam perspektif politik hukum pada dimensi pertama yaitu regulasi perbankan syariah dalam kebijakan dasar (basic policy). Regulasi perbankan syariah dilakukan tentu karena adanya kebutuhan untuk merespons dinamika dan perkembangan perbankan syariah yang semakin marak di tanah air yang semakin hari semakin membutuhkan landasan hukum yang tegas dan jelas. Regulasi mengenai perbankan syariah tumbuh secara bertahap dan evolutif seiring dengan perkembangan perbankan syariah. Hal ini dapat dibuktikan dengan dimulainya regulasi perbankan syariah secara bertahap dari ketika masih berbentuk bank bagi hasil pada UU Nomor 7 tahun 1992. Selanjutnya diperkuat lagi pada UU Nomor 10 tahun 1998 dengan istilah bank yang beroperasi sesuai prinsip syariah. Hingga akhirnya dikukuhkan secara mandiri dalam UU Nomor 21 tahun 2008 dengan istilah yang lebih tegas yaitu Perbankan Syariah.

${ }^{27}$ Gala Perdana Lubis, "Analisis Putusan Mahkamah Konstitusi No 93/PUU-X/2012 terhadap Penyelesaian Sengketa Perbankan Syariah di Indonesia" (Tesis: Fakultas Hukum Universitas Sumatera Utara, Tesis, 2014), h. 9 
Kondisi di atas menunjukkan bahwa regulasi perbankan syariah bukan sesuatu yang sekali jadi. Regulasi perbankan syariah menjalani tahapan proses yang dapat dikatakan sebuah evolusi. Apalagi terjadi drama yang diakibatkan oleh penjelasan Pasal 55 ayat (2) UU Nomor 21 tahun 2008 yang memberikan pilihan forum penyelesaian sengketa perbankan syariah kepada Peradilan Agama dan Peradilan Negeri. Tentu hal ini dapat menyebabkan ketidakpastian hukum dan tumpang tindih kewenangan di antara dua lembaga peradilan tersebut. Oleh karenanya dalam perspektif kebijakan dasar dapat dipahami bahwa regulasi perbankan syariah dalam perspektif politik hukum adalah sebagai landasan hukum bagi industri perbankan syariah untuk memperoleh kepastian hukum.

Pada dimensi kedua politik hukum menelaah tujuan pemberlakuan regulasi perbankan syariah. Terdapat sejumlah faktor yang menjadi dasar pemberlakuan regulasi perbankan syariah. Pertama, dalam timbangan teori utility. Secara teoritis, utilitarisme berpandangan bahwa hukum seharusnya dibuat untuk kepentingan masyarakat. Hukum harus mampu melindungi segala kepentingan masyarakat, baik perseorangan maupun badan hukum. Kepentingan masyarakat itu sendiri dapat diukur dengan tingkat terciptanya tujuan hukum itu sendiri, yaitu keadilan, kemanfaatan dan kepastian hukum, demi terlindunginya kepentingan masyarakat luas. Secara filosofis teori utility dapat dijelaskan melalui kerangka pemikiran John Stuart Mill, bahwa teoritis utility dapat dikelompokkan pada 2 (dua) kerangka dasar. Pertama, prinsip dasar sebuah tindakan dapat disebut benar apabila berupaya untuk menciptakan kebaikan dan menghindarkan segala yang dapat berimplikasi pada yang buruk. Kedua, keinginan dasar semua orang untuk melakukan kebaikan hidup secara kolektif. ${ }^{28}$

Merujuk pada kerangka dasar utility menurut Mill, dapat dipahami bahwa kebaikan mampu memberi dampak positif bagi kepentingan masyarakat atau kebalikannya menghindari yang buruk, sebagai tujuan dari pelaksanaan hukum. Secara sederhana dapat disebut, bahwa utility merupakan kerangka dasar hukum untuk menjaga dan mengatur terlaksananya kebaikan bagi kepentingan masyarakat. Merujuk pada fungsinya, teori utility yang dianggap sebagai bentuk dari mencapai terbesar (the greatest happiness) yang dijadikan sebagai landasan etik pelaksanaan hukum, maka teori utility sebagai kerangka kerja dalam upaya melihat politik hukum perbankan syariah, tentu harus dapat dipastikan untuk tercapainya manfaat hukum tersebut. Jika tidak mencapai manfaat hukum, maka pelaksanaan hukum tersebut sesungguhnya tidak memberikan kontribusi manfaat bagi masyarakat.

Secara lebih teknis, teori utility dijadikan kerangka teori hukum dengan prinsip dasar, bahwa setiap tindakan yang dilakukan semua orang ditujukan untuk mencapai kebahagiaan yang diukur dengan tingkat daya gunanya. Menurut Mill, teori utility sebagai moralitas harus melindungi semua orang, secara tegas ia mengatakan, ${ }^{29}$ "The moralities which protect every individual from being harmed by others, either directly or by being hindered in his freedom

\footnotetext{
${ }^{28}$ John Stuart Mill, the Collected Work of John Stuart Mill (Toronto: University of Toronto Press, 1991), h. 230.

${ }^{29}$ Mill, The Collected Work, h. 256.
} 
of pursuing his own good, are at once those which he himself has most at heart, and those which he has the strongest interest in publishing and enforcing by word and deed...; it is these moralities primarily, which compose the obligations of justice."

Demikian juga keadilan bersumber dari naluri manusia menghindarkan segala bentuk yang buruk, baik untuk diri sendiri ataupun orang lain. Keadilan merupakan syarat utama terbentuknya moral yang sebenarnya bagi kepentingan kesejahteraan bagi manusia. Teori utility ini apabila dilihat dalam kerangka kerja hukum, terutama dalam upaya perumusan dan penerbitan hukum harus mereferensikan nilai keadilan bagi semua orang, maka regulasi yang muncul seharusnya mampu memberikan kebahagiaan kepada masyarakat yang menjadi objek UU tersebut.

Prinsip pembentukan hukum atau UU dalam teori utility harus mewujudkan tujuan asasi kemanusiaan tentang kebahagiaan. Pertama, untuk memberikan nafkah hidup (to provide subsistence). Kedua, untuk memberikan makanan yang berlimpah (to provide abundance). Ketiga, untuk memberikan perlindungan (to provide security). Keempat, untuk mencapai persamaan (to provide equity). Merujuk pada prinsip kemanfaatan yang menjadi dasar teori utility ini harus menciptakan kepastian hukum dan keadilan hukum, maka tentu perumusan dan penerbitan UU harus diatribusikan untuk memberikan kebaikan kepada seluruh masyarakat.

Tentu saja pemerintah harus bertanggung jawab untuk mewujudkan prinsip kemanfaatan, karena pemerintah adalah pemegang kekuasaan dalam mencapai tujuan nasional. Posisi pemerintah dalam hal ini menurut Mill, ${ }^{30}$ "The only government which can fully satisfy all the exigencies of the social state is one in which the whole people participate; that any participation, even in the smallest public function, is useful; that the participation should everywhere be as great as the general degree of improvement of the community will allow, and that nothing less can be ultimately desirable than the admission of all to share in the sovereign power of the State."

Merujuk pada prinsip keadilan Mill yang dikemukakan, tentu peran pemerintah menjadi penting sebagai aparat yang harus memperhatian kepentingan masyarakat, terutama memastikan fungsi sosial dapat berjalan sebagaimana mestinya. Selain itu, pemerintah juga harus menciptakan masyarakat yang terlibat aktif di dalamnya dengan menjaga keutuhan dan persatuan masyarakat.

Teori utility dianut oleh utilitarianisme yang merupakan teori yang menghubungkan korelasi antara hukum dan ekonomi. Teori ini berpandangan, bahwa hukum dibangun atas dasar kemanfaatan, maka kaitannya dengan ekonomi akan dipandang baik apabila memberi manfaat kepada sebagaian besar masyarakat. Untuk menjalankan teori utility ini akan digunakan kerangka yang digunakan J.S. Mill dan Jeremy Bentham, yang menempatkan 3 (tiga) kerangka acuan manfaat yang dimaksudkan dalam tersebut. Pertama, manfaat

${ }^{30}$ Ibid., h. 403. 
merupakan kebijaksanaan yang mendatangkan manfaat atau kegunaan tertentu. Kedua, manfaat merupakan kebijakan yang mendatangkan manfaat besar dibanding dengan kebijaksanaan alternatif. Ketiga, manfaat merupakan sebuah tujuan yang bertujuan untuk masyarakat. ${ }^{31}$

Dalam timbangan teori utility ini regulasi perbankan syariah dipandang sebagai sesuatu yang baik dan memberi manfaat kepada sebagian besar masyarakat Indonesia. Hal ini dirasa wajar karena mayoritas penduduk Indonesia menganut agama Islam. Oleh karenanya pemberlakuan sejumlah regulasi perbankan syariah dan Putusan MK Nomor 93/PUU$\mathrm{X} / 2012$ juga dapat dilihat sebagai suatu upaya memberikan kepastian hukum bagi industri perbankan syariah dan menegakkan keadilan atas kewenangan Peradilan Agama sebagai lembaga yang telah diamanahi menyelesaikan sengketa ekonomi syariah secara absolut dalam UU Nomor 3 tahun 2006 tentang Peradilan Agama.

Sesungguhnya teori utilitty ini dapat dipadankan dengan teori maslahat yang berkembang dalam dunia Hukum Islam. Al-Mashlahat merupakan sebuah upaya mewujudkan kemanfaatan dan menghindari kemudaratan (jalbu al-mashâliḩ wa dar'u al-mafâsid). ${ }^{32}$ Tujuan syariat menurut al-Syatîbî diturunkan adalah untuk menciptakan kemaslahatan bagi umat manusia baik di dunia maupun di akhirat secara bersama-sama. ${ }^{33}$

Dalam konteks maslahat inilah negara memandang perlu memberikan pengaturan (regulasi) yang jelas tentang keberadaan perbankan syariah. Perbankan syariah tidak hanya berkaitan khusus dengan masyarakat Muslim Indonesia, tetapi juga terkait dengan kepentingan negara secara luas. Oleh karenanya, pengaturan perbankan syariah diharapkan mampu mencapai tujuan kemaslahatan masyarakat luas dan juga kemaslahatan negara di bidang ekonomi.

Kedua, dalam timbangan teori positifisasi hukum Islam regulasi perbankan syariah dalam sejumlah Peraturan dan Perundang-undangan dapat dilihat sebagai salah satu upaya pemberlakuan hukum Islam dalam sistem hukum nasional di Indonesia. Keberlakuan suatu hukum dalam sistem hukum nasional umumnya diukur dalam sejumlah teori, yaitu antara lain

\section{Teori Receptio in Complexu}

Sejak abad ke 19, di Indonesia berlaku hukum Islam sebagaimana pendapat Solomon Keyzer (1823-1868). Pendapat ini diperkuat oleh L.W. Christian Van den Berg dengan pernyataan

${ }^{31}$ J.S. Mill dan Jeremy Bentham, Utilitarism and Other Essays (London: Penguin Book Ltd, 2004), h. 5.

${ }^{32}$ Imran Ahsan Khan Nyazee, Theories of Islamic Law: the Methodology of Ijtihad (Kuala Lumpur: The Other Press, 2002), h. 212.

${ }^{33}$ Abî Ishâq Ibrâhîm al-Syâthîbî, al-Muwâfaqât fĩ Ushûl al-Syarî’ah, Juz II (Beirut: Dâr Kutub al-'Ilmiyah, t.t.), h. 5-8. 
bahwa hukum mengikuti agama yang dianut seseorang. Jika orang itu memeluk agama Islam, maka hukum Islamlah yang berlaku baginya. Menurut Berg, orang Islam Indonesia telah melakukan resepsi hukum Islam dalam keseluruhannya dan sebagai satu kesatuan yang disebut dengan receptio in complexu. ${ }^{34}$

Materi teori receptio in complexu dimuat dalam pasal $75 \mathrm{RR}$ (Regeeringsreglement) tahun 1855. Pasal 75 ayat 3 RR berbunyi "oleh hakim Indonesia itu hendaklah diberlakukan UU agama (godsdienstige wetten) dan kebiasaan penduduk Indonesia itu." Hukum Islam berlaku bagi orang Islam dengan istilah godsdienstige wetten. Pada masa teori ini keluar stbl.1888 Nomor 152 tentang pembentukan Pengadilan Agama (Priesterrad) di samping Pengadilan Negeri (landraad), yang sebelumnya didahului dengan penyusunan kitab yang berisi himpunan hukum Islam, pegangan para hakim, seperti Mogharrer Code pada tahun 1747, Compendium Freijer pada tahun $1761 .{ }^{35}$

\section{Teori Receptio}

Teori receptio in complexu dibantah oleh Snouck Hurgronje (1857-1936) yang saat itu menjadi penasehat pemerintahan Hindia Belanda urusan agama Islam dan bumi putra dengan teorinya yang disebut receptio. ${ }^{36}$ Menurut Snouck, hukum yang diberlaku bagi orang Islam adalah hukum adat. Hukum Islam berlaku jika telah diterima hukum adat. Teori ini menjadi terkenal setelah disistematisasikan dan dikembangkan oleh Cornelis van Vollenhoven dan Ter Haar dan para pengikutnya. Teori ini sangat sistematis mengerdilkan bahkan menghapuskan keberlakuan hukum Islam di Indonesia. Keberlakukan hukum Islam (dalam arti materil) maupun dalam proses peradilan (dalam arti formil) dihapus. Pada saat teori ini berlaku, politik hukum Islam benar-benar berada pada kemunduran bahkan dalam jurang kehancuran.

\section{Teori Receptio Exit}

Munculnya teori receptio seperti yang dikemukakan di atas menimbulkan penentangan di kalangan para ahli hukum Islam sebab, menurut Hazairin, teori yang dikemukakan

\footnotetext{
${ }^{34}$ Mohammad Daud Ali, Hukum Islam: Pengantar Ilmu Hukum dan Tata Hukum Islam di Indonesia (Jakarta: Rajawali Press, 1998), h. 241.

${ }^{35}$ Suparman Usman, Hukum Islam Asas-Asas dan Pengantar Studi Hukum Islam dalam Tata Hukum Indonesia (Jakarta: Gaya Media Prata, 2001), h. 112.

${ }^{36}$ Teori Reception menurut Mohammad Daud Ali dalam kepustakaan hukum mengandung arti bahwa norma hukum tertentu atau keseluruhan aturan hukum tertentu diambilalih dari perangkat hukum yang lain. Dalam hubungan ini menurut sejarah hukum Eropa resepsi telah dilakukan oleh hukum Romawi sebelumnya, dan hukum Romawi telah diresepsikan pula oleh hukum banyak negara di Eropa, ada yang banyak dan ada pula yang sedikit atau sebagian. Mohammad Daud Ali, Hukum Islam: Pengantar Ilmu Hukum dan Tata Hukum Islam di Indonesia, h. 242, dalam foonote.
} 
oleh Snouck Hurgronje adalah teori iblis (teori setan). Teori ini hendak mematikan hukum Islam yang telah diterima oleh masyarakat Indonesia dan merupakan suatu ajakan kepada umat Islam untuk tidak patuh dalam melaksanakan perintah Allah dan Rasul. Pada saat Indonesia merdeka, Hazairin mengatakan: ${ }^{37}$

Pemahaman inilah yang dimaksud dengan matinya atau hapusnya teori receptie atau keluarnya dari teori receptio yang disebut dengan Receptie exit. Berlakunya teori receptio exit diawali pengesahkan UUD 1945 oleh PPKI pada tanggal 17 Agustus 1945. Bagian pem-bukaannya merupakan Piagam Jakarta yang merupakan keberhasilan dari tokoh tokoh kebangsaan yang selalu memperjuangkan berlakuya hukum Islam. Walaupun dalam piagam tersebut telah dihapuskan tujuh kata ("dengan kewajiban menjalankan syari'at Islam bagi pemeluk-pemeluknya") namun di dalamnya terdapat landasan filosofis adalah Pancasila sebagaimana rumusannya terdapat dalam alinea keempat Pembukaan UUD 1945 dan landasan yuridis yang terdapat dalam pasal 29 UUD 1945 tentang kebebasan pemberlakuan hukum agama bagi pemeluknya.

Keberlakuan hukum Islam akhirnya dimasukkan dalam rumusan dasar negara Republik Indonesia yang dikenal dengan Piagam Jakara yang berbunyi: "Negara berdasarkan kepada Ketuhanan dengan kewajiban menjalankan syariat Islam bagi pemeluknya." Tujuh kata terakhir ini yang semula tercantum dalam Piagam Jakarta dihapus oleh Panitia Persiapan Kemerdekaan Indonesia (PPKI).

Namun melalui dekrit Presiden RI tanggal 5 Juli 1959 yang menyatakan kembali ke UUD 1945, Soekarno mengatakan bahwa "kita percaya bahwa piagam Jakarta yang ditulis tanggal 22 Juni 1945 adalah inspirasi di belakang UUD 1945, dan adalah bagian yang integral dari konstitusi ini." ${ }^{38}$ Dalam sejarah pembentukan dasar negara bahwa sila pertama berasal dari piagam Jakarta yang berbunyi "negara berdasarkan atas Ketuhanan Yang Maha Esa, dengan kewajiban menjalankan syariat Islam bagi pemeluknya. ${ }^{39}$

\section{Teori Receptio a Contrario}

Teori Receptio a contrario adalah juga teori bantahan terhadap teori Receptio. Teori

\footnotetext{
${ }^{37}$ Hazairin, Hukum Keluarga Nasional (Jakarta: Tintamas, 1982), h. 7-8.

${ }^{38}$ Rifyal Ka'bah, the Jakarta Charter and the Dynamic of Islamic Syariah in the History of Indonesian Law (Jakarta: University of Indonesia School of Law Post Graduate Studies Program, 2006), h. 7; Muhammad Hatta, Sekitar Proklamasi (Jakarta: Tintamas, 1971), h. 57-59.

${ }^{39}$ Dalam sejarah pembentukan Pancasila sebagai dasar negara, semula golongan Islam menghendaki Islam sebagai dasar negara, namun dalam perdebatan dan kompromi, Islam tidak dijadikan dasar negara (dan agama negara), tetapi terjadi perubahan dalam tata urut Pancasila dari susunan yang dikemukakan Soekarno pada tanggal 1 Juni. Prinsip "Ketuhanan" dipindah dari sila terakhir ke sila pertama, ditambah dengan anak kalimat "dengan kewajiban menjalankan syariat Islam bagi pemeluk-pemeluknya" (kemudian dikenal dengan istilah "tujuh kata"). Lihat, Yudi Latif, Negara Paripurna: Historitas, Rasionalitas, dan Aktualitas Pancasila (Jakarta: Gramedia Pustaka Utama, 2011), h. 24.
} 
Receptio a contrario dicetuskan oleh Hazairin dengan pernyataan bahwa teori resepsi tidak dapat dipergunakan untuk melihat kenyataan-kenyataan dan masalah-masalah dasar hukum di Indonesia. Menurut Hazairin, keistimewaan hukum agama adalah bahwa hukum agama itu bagi rakyat Islam dirasakan sebagai bagian dari perkara iman.

Teori ini merupakan kebalikannya dari teori Receptio, di mana hukum adat baru berlaku jika tidak bertentangan dengan hukum Islam. Di beberapa daerah yang dianggap sangat kuat adatnya, seperti di masyarakat Aceh yang menghendaki perkawinan dan kewarisan diatur dan disesuaikan dengan hukum Islam. Bila berlaku hukum adat dapat juga diterima apabila tidak bertentangan dengan Hukum Islam.

Oleh karenanya kenyataan adanya regulasi perbankan syariah saat ini di Indonesia mengukuhkan eksistensi teori receptio exit dan receptio a contrario yang meneguhkan teori positifisasi hukum Islam serta sekaligus menolak eksistensi teori receptio. UU Nomor 3 tahun 2006 tentang Peradilan Agama dan UU Perbankan Syariah Nomor 21 tahun 2008 tentang Perbankan Syariah merupakan bentuk formalisasi hukum Islam menjadi hukum positif di Indonesia.

Positifisasi hukum Islam dengan menggunakan hukum Islam sebagai salah satu sumber hukum nasional didasarkan pada UU Nomor 17 tahun 2007 tentang Rencana Pembangunan Jangka Panjang Nasional Tahun 2005-2025 sebagai Pengganti Garis-Garis Besar Haluan Negara. Positifisasi hukum Islam dengan menggunakan hukum Islam disandarkan pada dasar Negara Pancasila yaitu sila pertama Ketuhanan Yang Maha Esa dan UUD 1945 pada pasal 29 ayat (1) Negara berdasarkan Ketuhanan yang Maha Esa.

Dengan demikian, dalam konteks politik hukum dalam dimensi kebijakan pemberlakukan hukum (enactment policy) perbankan syariah dapat dijelaskan dalam dua faktor utama yaitu faktor internal dan faktor eksternal. Secara internal, hukum Islam diakui sebagai salah satu sumber dalam pembentukan sistem hukum nasional selain hukum adat (kebiasaan masyarakat) dan hukum Barat (Belanda) yang memiliki kedudukan yang sama dan seimbang.

Pemikiran pemberlakukan hukum Islam dalam sistem hukum nasional saat ini juga diperkuat oleh paradigma hukum profetik yang dikembangkan oleh Kuntowijoyo dan diperjelas oleh Heddy Shri Ahimsa-Putra. Gagasan hukum profetik diilhami oleh Muhammad Iqbal dan Roger Garaudy. Munculnya ilmu hukum profetik ini merupakan alternatif kajian keilmuan bagi hukum. Pemikiran hukum profetik berbasis pada nilai-nilai profetik yang sumber utamanya adalah wahyu ilahi. Oleh karenanya, al-Qur'an dan hadis dalam konteks paradigma hukum profetik menjadi basis utama epistemologinya. ${ }^{40}$

Masuknya hukum perbankan syariah dalam proses positifisasi hukum nasional menjadi bukti kuat bahwa hukum Islam adalah hukum yang diakui sebagai salah satu

${ }^{40}$ M. Syamsuddin (ed.), Ilmu Hukum Profetik: Gagasan Awal, Landasan Kefilsafatan dan Kemungkinan Pengembangannya di Era Postmodern (Yogyakarta: Pusat Studi Hukum FH UIIFH UII Press, 2013). 
sumber hukum nasional dan memungkinkan paradigma hukum profetik menjadi salah satu alternatif di dalam kajian ilmu hukum. Proses regulasi perbankan syariah mulai dari penyusunan hingga pemberlakuan sudah melalui proses demokratisasi sebagaimana sumber hukum lainnya. Proses demokratisasi di sini memiliki arti penting karena bermakna bahwa hukum Islam khususnya perbankan syariah yang dipositifisasi dalam sistem hukum nasional diyakini bermanfaat dan memberikan kemaslahatan bagi masyarakat Indonesia dan memiliki tujuan yang seiring sejalan tujuan nasional di bidang ekonomi.

Secara eksternal, tuntutan perkembangan perbankan syariah di level global dan nasional tentu memerlukan landasan hukum yang tegas dan jelas. Hal ini mutlak untuk menciptakan kepastian hukum. Seiring dengan perkembangan market share perbankan syariah tentu berpotensi menimbulkan berbagai persoalan yang mengiringinya. Kepastian dan keadilan hukum dalam regulasi perbankan syariah semakin kukuh pasca terbitnya Putusan MK Nomor 93/PUU-X/2012 yang meneguhkan kewenangan absolut peradilan agama untuk menyelesaikan sengketa ekonomi syariah.

\section{Penutup}

Pemberlakuan hukum perbankan syariah dalam sistem hukum nasional di Indonesia dilakukan lewat proses evolusi bertahap. Pada tahapan awal regulasi perbankan syariah masih diatur secara minimal pada UU Nomor 7 tahun 1992 dengan mengakomodasi bank dengan prinsip bagi hasil. Pada tahap ini, regulasi perbankan syariah merupakan respons terhadap praktik bank syariah yang masih dipandang masih dalam bentuk bank dengan prinsip bagi hasil. Pada tahap selanjutnya, regulasi perbankan syariah diatur dalam UU Nomor 10 tahun 1998 dengan mengakomodasi bank dengan prinsip syariah. Pada dua regulasi ini, bank syariah diregulasi bersamaan dengan aturan yang sama dengan yang mengatur bank konvensional. Akhirnya, terbitlah UU Nomor 21 tahun 2008 yang meregulasi perbankan syariah secara terpisah dari bank konvensional. Sempat terjadi drama dalam panggung politik hukum nasional berkaitan dengan regulasi perbankan syariah ini. Dalam UU Nomor 3 tahun 2006 diatur bahwa Peradilan Agama memiliki kompetensi absolut dalam menyelesaikan sengketa ekonomi syariah. Namun, dalam penjelasan pasal 55 ayat (2) masih diberikan pilihan (choice of forum) bagi para pihak menyelesaikan sengketa ekonomi syariah di antara Peradilan Agama dan Peradilan Negeri. Akhirnya setelah terbitnya Putusan MK Nomor 93/PUU-X/2012 semua penjelasan Pasal 55 ayat (2) UU Nomor 21 Tahun 2008 tentang perbankan syariah diputuskan bertentangan dengan konstitusi dan tidak memiliki kekuatan hukum mengikat.

Dalam perspektif politik hukum, realitas dinamika regulasi perbankan syariah memiliki makna tersendiri. Politik hukum mengandung dua dimensi dalam mengkaji sebuah regulasi yaitu dari dimensi kebijakan dasar mengapa suatu regulasi diundangkan (basic policy) dan dimensi kebijakan pemberlakuan (enactment policy). Dari sudut kebijakan dasar regulasi 
perbankan syariah diadakan untuk menjamin terciptanya kepastikan hukum bagi industri perbankan syariah yang terus bertumbuh dan berkembang di tanah air. Dalam hal ini terbitnya Putusan MKNomor 93/PUU-X/2012 semakin menguatkan regulasi terkait perbankan syariah selain untuk menciptakan kepastian hukum juga untuk menegakkan keadilan hukum. Respon atas pertumbuhan dan perkembangan industri perbankan syariah di tanah air ini menjadi faktor eksternal lahirnya regulasi perbankan syariah dalam tatanan hukum nasional.

Dari dimensi kebijakan pemberlakukan regulasi perbankan syariah yang dipositifisasi dalam sistem hukum nasional diyakini bermanfaat (utility) dan memberikan kemaslahatan bagi masyarakat Indonesia dan memiliki tujuan yang seiring sejalan tujuan nasional di bidang ekonomi. Dalam teori positifisasi hukum, pemberlakuan perbankan syariah dalam sistem hukum nasional memperkuat keberadaan teori receptio exit dan receptio a contrario yang meneguhkan teori positifisasi hukum Islam dan sekaligus menolak eksistensi teori receptio. Dalam paradigma hukum profetik, pemberlakuan hukum perbankan syariah menjadi salah satu penguat bahwa hukum Islam yang didasarkan pada nilai-nilai ajaran Islam adalah salah satu alternatif bidang kajian hukum yang patut dikembangkan dan menjadi salah satu elemen dalam pembinaan dan pembangunan hukum nasional.

\section{Pustaka Acuan}

Abduh, Muhammad dan Omar Mohd Azmi. "Islamic Banking and Economic Growth: The Indonesia Experience," dalam International Journal of Islamic and Middle Eastern Finance and Management, Vol. 5, No. 1, 2008.

Ali, Mohammad Daud. Hukum Islam: Pengantar Ilmu Hukum dan Tata Hukum Islam di Indonesia. Jakarta: Rajawali Press, 1998.

Al-Syâthîbî, Abî Ishâq Ibrâhîm. al-Muwâfaqât fî Ushûl al-Syarî’ah, Juz II. Beirut: Dâr Kutub al-'Ilmiyâh, t.t.

Ariff, Mohamed. "Islamic Banking: A Southeast Asian Perspective," dalam Mohamed Arif, (ed.). Islamic Banking in Southeast Asia. Singapore: Institute of Southeast Asian Studies, 1988.

Fealy, Greg dan White, Sally. Expressing Islam: Religious Life and Politicts in Indonesia. Singapore: Institute of Southeast Asian Studies, 2008.

Hatta, Muhammad. Sekitar Proklamasi. Jakarta: Tintamas, 1971.

Hazairin. Hukum Keluarga Nasional. Jakarta: Tintamas, 1982.

Ismal, Rifki. Islamic Banking in Indonesia: New Perspectives on Monetary and Financial Issue. England: John Wiley \& Sons, Ltd, Chichester, 2013.

Juwana, Hikmahanto, et al. "Sharia Law as A System of Governance in Indonesia: The Development of Islamic Financial Law," dalam Wiscoinsin International Law Journal, Vol. 25, No. 4, 2008. 
Juwana, Hikmahanto. "Politik Hukum UU Ekonomi di Indonesia," dalam Jurnal Hukum, Vol. 01, Tahun 2005.

Ka'bah, Rifyal. The Jakarta Charter and the Dynamic of Islamic Syariah in the History of Indonesian Law. Jakarta: University of Indonesia School of Law Post Graduate Studies Program, 2006.

Latif, Yudi. Negara Paripurna: Historitas, Rasionalitas, dan Aktualitas Pancasila. Jakarta: Gramedia Pustaka Utama, 2011.

Lubis, Gala Perdana. "Analisis Putusan Mahkamah Konstitusi No 93/PUU-X/2012 terhadap Penyelesaian Sengketa Perbankan Syariah di Indonesia." Tesis: Fakultas Hukum Universitas Sumatera Utara, 2014.

Mannan, Abdul. "Hukum Perbankan Syariah," dalam Jurnal: Mimbar Hukum dan Peradilan, Vol. 1, No. 7, 2012.

Mill, J.S. dan Bentham, Jeremy. Utilitarism and Other Essays. London: Penguin Book Ltd, 2004.

Mill, John Stuart. The Collected Work of John Stuart Mill. Toronto: University of Toronto Press, 1991.

Nyazee, Imran Ahsan Khan. Theories of Islamic Law, the Methodology of Ijtihad. Kuala Lumpur: The Other Press, 2002.

Salim, Arskal dan Azyumardi Azra (ed.). Shari'a and Politics in Modern Indonesia. Singapore: Institute of Southeast Asian Studies, 2003.

Salim, Arskal. Contemporary Islamic Law in Indonesia: Sharia and Legal Pluralism. Edinburgh: Edinburgh University Press Ltd, 2005.

Syamsuddin, M. (ed.). Ilmu Hukum Profetik: Gagasan Awal, Landasan Kefilsafatan dan Kemungkinan Pengembangannya di Era Postmodern. Yogyakarta: Pusat Studi Hukum FH UII-FH UII Press, 2013.

Usman, Suparman. Hukum Islam Asas-Asas dan Pengantar Studi Hukum Islam dalam Tata Hukum Indonesia, Cet. 2. Jakarta: Gaya Media Prata, 2001.

Wilson, Rodney. Legal, Regulatory and Governance Issues in Islamic Finance. Edinburgh: Edinburgh University Press, 2012. 